\title{
Thyrocerebrorenal syndrome
}

INSERM

\section{Source}

INSERM. (1999). Orphanet: an online rare disease and orphan drug data base.

Thyrocerebrorenal syndrome. ORPHA:3327

Thyrocerebrorenal syndrome is characterized by renal, neurologic, thyroid disease, associated with thrombocytopenia. It has been described in a brother and his sister. Intelligence was normal. It is transmitted as an autosomal recessive trait. 